Education and sustainability: Reinvigorating adult education's role in transformation, justice and development

\author{
Catherine Casey \\ Professor of Organization and Society \\ School of Management \\ University of Leicester \\ Leicester LE1 7RH \\ Phone +441162523358 \\ email: c.casey@leicester.ac.uk
}

and

Lily Asamoah

Non-Formal Education Division

Ministry of Education, Ghana

Email: lilyasam23@hotmail.com 


\title{
Education and sustainability: Reinvigorating adult education's role in transformation, justice and development
}

\begin{abstract}
Distinctively economic objectives for lifelong education, especially adult learning and education, feature prominently in policy-making agendas and educators' practice in much of the world. Critics contend that humanistic and holistic visions of lifelong learning for all have been marginalised and neglected. The current turn of political attention to issues of planetary environmental sustainability and to global societal transformation and inter-connectedness raises further questions and prospects. Two United Nations' publications in 2015:

UNESCO's Rethinking Education: toward a global common good? and of the United Nations' Transforming our world: the 2030 Agenda for Sustainable Development pose intersecting concerns for lifelong learning and environmental sustainability.

This article engages with those questions in particular regard to the role of adult learning and education. It discusses a case study of non-formal adult education in Ghana. The case contributes evidence that resiliently humanistic conceptions and practices of nonformal adult education practically succeed to foster transformation, development and human flourishing. That effective humanism gives credence to the ambitiousness of UNESCO and UN agenda for transformation and sustainability and informs international debates.
\end{abstract}

\section{Keywords: humanistic lifelong learning, sustainable development goals, Ghana, empowerment}

\section{Introduction}

Much debate in lifelong learning and adult education literature over recent decades expresses concern about the directions and uses of education and lifelong learning in many societies. For many researchers and practitioners, as well as UNESCO policy advisors, the 
concept of lifelong learning is intended to expresses a broadly inclusive humanistic principle of learning throughout the life-course for human emancipation and flourishing for all. It is intended to fully recognise and include adult learning along with education achieved earlier in life. Lifelong learning is also an organising principle for all forms of education. It includes formal, non-formal and informal modes of provision and participation in education and learning along with avenues, especially throughout adult life, of flexible and recurrent uptake of education and learning opportunities. Lifelong learning, for UNESCO, plays a critical role in addressing global educational issues and challenges. Lifelong learning proposes to enrich every person's life and is the path to building learning and sustainable societies. Adult education is an indispensable part of lifelong learning systems. Adult learning and education, UNESCO (2010a) contends, is imperative for the achievement of equity and alleviating poverty and for forging 'more democratic, peaceful, inclusive, productive, healthy and sustainable societies'.

This aspirational vision for lifelong learning and adult education is under severe pressure. Powerful forces of neoliberal economics, globally competitive market expansion and rapid technological advancement pressure policy-makers to adopt distinctively economic objectives for lifelong learning, especially adult learning and education. Human capital models of education propose to maximize education's direct utility to generating economic growth, competitiveness and marketization. Amid these concerns about conceptions and uses of lifelong learning, many fear a secular demise of humanistic and holistic visions of lifelong learning and a technocratic ascendancy in education. Certainly, in developed countries, the narrowing of the educational vision in regard to what education systems produce in schools and in adult education programmes has greatly setback an ethos of humanistic education for all promoted by a $20^{\text {th }}$ century social democratic tradition.

At the same time, the rise of political attention to issues of planetary environmental change and sustainability adds another dimension of prospects for adult learning and education. Two United Nations' publications in 2015 are especially pertinent in addressing intersecting concerns for education and lifelong learning and environmental sustainability. 
The publication of UNESCO's Rethinking Education: toward a global common good? (UNESCO 2015a) expresses in plain language its fresh commitment to a humanistic approach to education. Nearly twenty years after the Delors Report, Learning: the treasure within (1996), Rethinking Education reasserts that learning throughout life for social, economic and cultural development that is based on sound ethical and moral foundations is vital for achievement of human development and socially just global society. Redressing widening income inequality and precarious social cohesion evident in current decades and sustaining peaceable societies requires imaginative and concerted development of education and lifelong learning.

Alongside Rethinking Education, the United Nations also launched its agenda for sustainable development. Transforming our world: the 2030 Agenda for Sustainable Development was agreed at a UN general assembly for enactment in 2016. Signatories have declared that they have embarked upon a 'supremely ambitious and transformational vision' for addressing interconnected economic, social and environmental challenges and transforming the world. Quality education for all is at the heart of their pursuit.

These extensive international policy agendas invite fresh questions and engagement. The declared ambitiousness of the UN's documents and their respective visions and programmes may inspire among national policy actors and educationists renewed enthusiasm and commitment to a post-economistic vision for lifelong learning. Or, conversely, the highly ambitious proclamations may meet jaded wariness. For some, they may reflect the wishful idealism of out-of-touch elites and pose little practical intervention. Economistic and technocratic education and skills training have gained a tenacious hold at national policy levels. Education systems and outcomes have inadvertently enabled accelerated advances for some and worsened global inequalities Prospects for humanistic reshaping and enrichment of education and lifelong learning agenda toward transformative education for all appear remote.

In this article, we propose that the two related agendas pose fresh and potent political scope for lifelong learning. How can the new opportunities implied for lifelong 
learning be taken up? In contributing to wider debates in response to that challenging question, we address in particular adult learning and education. We offer illustration of a case study of non-formal adult learning and education in Ghana. The study, described below, shows how local people hold and enact their humanistic vision and approach to education while pursuing capabilities for sustainable economic development. The Ghana case, we hope, may help international debates that are often sensitive to too much one-way travel of Eurocentric policy-making and intellectual focus (Webb et al. 2015). An apparent degradation or truncation of lifelong learning and instrumentalism of formal adult education in developed countries is a cause for concern, but for low-income countries lifelong learning and adult education present a different picture. Our study, which emphasises voices from the 'global south' (UNESCO 2015b) may propose re-forged openings for education actors' intervention in heavily economistic reductionism of education and lifelong learning, especially adult education. In short, our case contributes evidence that resiliently humanistic conceptions and practices of lifelong learning, in particular non-formal adult learning, persist and practically succeed to foster human flourishing. It gives credence to the lofty ambitiousness of UNESCO and UN agenda for transformation and sustainability.

The article is structured as follows. Firstly, to set the context of our article, we briefly review debates in which lifelong learning and adult education research and practice are often criticised for being narrowly instrumentalist and subservient to the demands of global economic actors. We then discuss the two UN policy agendas launched in 2015 cited above. We identify features that present opportunity for promotion and practice of inclusive humanistic approaches to lifelong learning. We then introduce and discuss the findings of a field study in Ghana. Further discussion and concluding remarks follow.

\section{Lifelong learning and Adult learning and education: from holistic development to instrumentality?}

A considerable body of literature in adult learning and education since efforts of the early $20^{\text {th }}$ century in workers and women's education has emphasised the emancipatory and 
transformational potential of ALE (Jarvis 2010). A stream of studies in adult education has promoted, along with the benefits to the individual learner and her family, the political potential of adult learning and education provision and participation to generate collective resources for substantive social change (Friere 1968; Denys 2013; Welton 1993). That social change includes human development of excluded or disadvantaged sectors of society and reform of elite powers and their traditional political advantages. The humanistic vision for adult education, displayed in that literature and encouraged by global bodies notably UNESCO since its foundation and famously in its Faure Report, Learning to Be (Faure 1972), widely influenced adult education practitioners and various social-democratic governments in policy formation and implementation in the latter $20^{\text {th }}$ century. It sparked an early conception of lifelong learning and education in which adult learning and education were part of wide and long human development from cradle to grave.

For many researchers, especially in developed countries, that humanistic vision however had founded by the turn of the $21^{\text {st }}$ century. The notion of lifelong learning with its humanistic ethos remains for many educationists and policy makers an attractive, inclusive universal organising principle. But the rise of economic interests in lifelong learning for developing workforces and competitive economies has shifted the focus. A more explicitly economic and instrumental conception of lifelong learning that focusses on skills development for often unpredictable labour market requirements, has marginalised the humanistic aspiration. Adult education researchers have variously traced the rise and fall from prominence of humanistic agenda for adult learning and education (Elfert 2015; Rubenson 2011; Schuetze and Casey 2006). Economic interests in adult education have always comprised a significant feature. Participants can be just as interested in the costbenefit equation of their investment as governments or other agencies funding its provision. Governments and are interested in the economic returns, including productive innovation and market development, and in labour market development. For governments and citizens, learning to gain useful skills for employment as well as learning for diverse cultural 
enrichment has always featured in adult education. At issue, however, is not the place of economic and technological skills imperatives but their rise to predominance.

The political and economic influence of international organizations, such as the OECD and World Bank, over recent decades has pressured states for reform of national education and training systems for human capital development. OECD and World Bank advisories have emphasised formal education and training provision and qualification systems and marginalised non-formal provision. Adult education in particular, with its history of non-formal provision, plural objectives and difficult to calculate outcomes, has been targeted for rationalisation toward labour market utility. Under the flag of lifelong learning, adult education is explicitly directed to the generation of skilled workers for liberalised and highly competitive markets. As the World Bank succinctly expressed it: 'lifelong learning is education for the knowledge economy' (World Bank 2003).

The neo-liberal, human capital oriented model of lifelong learning has achieved a powerful hold in the field of education and lifelong learning. Its influence on European Commission policy formation, which has in turn much influence beyond the European Union (Casey 2011) is welcomed by some (viz Rodrigues 2004) and greeted with alarm and criticism by others (Zarifis and Gravani 2014). Critics contend that the European Commission's policies on lifelong learning have adopted OECD and World Bank imperatives that are singularly intent on economic objectives and global market competitiveness. Field (2006) finds the European Commission a 'temple of human capital thinking' while many others regard lifelong learning as having degenerated into 'human resource development' and crude economic rationalism. Education for the cultivation and edification of the mind, body and soul has been relegated in favour of education and skills formation for technological competencies and labour market competitiveness.

Lifelong learning and adult education research and practice are frequently criticised for being as Heikkinen summarily (2012, page 67) puts it, 'too practical and pragmatic, shortsighted, small-scale, profit-oriented, fragmentary, depoliticized and normative'. The recent shift in international discourse from 'education' to 'learning' suggests, for many critics, not so 
much an emphasis on the perpetuity and creativity of learning as continuing education throughout life but a focus on individualism and competitiveness. The collective, social dimensions of education are elided. These are powerful critiques of both the notion of lifelong learning and of adult education which largely originated in a humanistic tradition and with holistic curricula for human development throughout the life course.

Other researchers contend that the dichotomous depiction of lifelong learning and adult education overlooks evidence of adult learning and education provisions in practice. Those provisions frequently continue to contain multiple objectives and outcomes for learners, including broad socio-cultural and human development along with practical and employment oriented skills. Researchers document ways in which adult learning of various forms can have significant personal and social as well as economic benefits (Livingstone and Guile 2012; Jenkins 2011; Manninen 2012; Walters and Watters 2001). Many observe social capital development that refers to qualities such as interpersonal and civic trust, social connections and engagement, and to personal features of resilience in the face of life difficulties, improved health and well-being (Fragoso et al. 2011; Schuller et al. 2004; UNESCO 2010b).

Economists, like educationists, similarly take careful note of these non-material capitals in relation to socio-economic wealth. The OECD reports (2014a) that 'learning begets learning', that people who participate in learning activities tend to continue to do so over the life-course. In addition to improved technical skill levels adults with higher levels of educational attainment are more likely to report that they experience good health and good degrees of social trust. Those positive associations between education and social effects apply across gender, age and income level (OECD 2014a). Individuals gain through education psycho-social features, competencies and attitudes that play an important role in social outcomes that are not attributable to economic benefits.

Nonetheless, alongside these reports of benefits to learners and their immediate communities, researchers also demonstrate that formal adult education is frequently politically diverted or captured by powerful actors to benefit the already advantaged and 
further exclude others. Opportunities to participate and reap the benefits of adult education are often disproportionately available to adults who already possess skills and facilities for further learning. Green and colleagues (Green 2011, Green et al. 2006) and Janmaat and Green (2013) demonstrate that provision of adult education can actually magnify and generate skills inequality across populations rather than diminish that inequality, a point also confirmed by OECD research (OECD 2014).

In this mixed picture of the fate of lifelong learning, it is clear that adult learning and education's contribution to more 'peaceful, democratic, inclusive, tolerant and sustainable societies', as declared in UNESCO's Belém Framework for Action (2010) is not readily evident around the globe. Adult learning and education evidently yields benefits, but emphasis on holistic development and emancipatory social change appears eclipsed by instrumental utility or elite capture. However, comparative international research on lifelong learning and political economies shows how the influence of neoliberal economic pressures emanating from international policy agencies differentially affect various national systems. That research shows that in addition to evidence of abandoned emphasis on holistic and emancipatory adult education in favour of skills for jobs education and training, there persists continuing variety in conceptions as well as practices of lifelong learning in different national and regional contexts around the world (Aman and Ireland 2015; Baba-Moussa, et al. 2014; Walters, et al. 2014). That evident variation - prominently from the global south - sharpens focus on wider social, economic, cultural, and political contexts in which lifelong learning is enacted. It highlights the ways in which policy is interpreted and enacted on the ground.

Policy bodies, notably the European Union Commission, the OECD and the World Bank, undoubtedly influence formation of policy agendas in education and lifelong learning at national levels. Yet, actors at national and regional levels necessarily interpret and mould those influences. Their enactments, as Baba-Moussa et al. (2014) and Denys (2013) notably demonstrate, are shaped by local contextual factors of preference, constraint and opportunities. Regmi (2015), furthermore, argues that despite heavy pressures from 'global north' institutions to shape lifelong learning in the least developed countries and to impose 
neoliberal models upon local values and practices, local leaders raise protest and demand alternatives. They refer to local cultural traditions that hold a humanistic conception of lifelong learning. The power of international bodies and global market forces may press a convergence toward economically instrumental lifelong learning as Regmi (2015) and other researchers in developed countries envisage. Or patterns of difference may persist in ways that enable alternatively progressive outcomes and prospects (Zeelen et al. 2011). We take up this point in discussing the Ghana case study below. We first discuss briefly the UN documents.

\section{UN Documents 2015: Rethinking Education and Transforming our World}

UNESCO's publication in 2015 of Rethinking Education: toward a global common good? arises from its recognition of a complex set of intersecting concerns affecting the world. We are living in 'turbulent times' that require fresh and urgent response. It observes that 'societies are undergoing deep transformation' and inequalities are worsening among human communities and societies. At the same time the planet is under pressure. These conditions, it declares, require 'that we revisit the purpose of education and the organization of learning.' The complexity of today's world requires a comprehensive approach to education policy.

The key message of the discussion paper is the assertion of education as a common good in which social, economic and cultural development are shared in common among the diverse peoples of the world. In that embrace, Rethinking Education endeavours to affirm an essential humanism that also recognizes diverse expressions and emphases. Its emphasis on commonality endeavours to find a foundational principle that can make the empirical worsening of inequalities among people and exclusion from common goods a shared responsibility. Its stress on the notion of the commons rather than the notion of public goods expresses its effort to distance its fresh thinking on education from any vestiges of economic rationality which may be found in utilitarian conceptions of public and private goods. 
The emphasis on common goods finds ready accord with UNESCO's vision and conceptualisations of adult learning and education over many decades. It is of especial usefulness in enabling reiteration of adult learning and education as multifaceted rather than economically utilitarian and inclusive for all people in societies. Those points, made in the Belém Framework for Action (UNESCO 2010), promote adult education and learning that simultaneously develop individual adults and their families and the common good of achieving sustainable socio-economic development and more equitable and peaceful societies.

In sum, Rethinking Education's emphasis on the commons - of goods, means and outcomes - of education promotes a human solidarity that potentially transcends the complexities of diverse cultural, social, economic, and political contexts around the world. It implicitly reinforces the Belém Framework and enables closer interaction with other UN goals and agenda. It lends a particular opportunity for a fresh assertion of the role of adult learning and education not only as a personal and community good but more inclusively as a common good. UNESCO $(2015 b)$ reports that 781 million adults lack basic literacy skills, of which $64 \%$ are women, a percentage unchanged since 2000 . Exclusion from basic education and literacy is exclusion from the commons of humanity. Its effect for women is persistent gender inequality and disempowerment.

Rethinking Education provides useful perspectives for a practical reading of the UN's Transforming our world: the 2030 Agenda for Sustainable Development. Compiled by a different set of contributors and aiming for a world-wide audience across all fields of sociopolitical action, Transforming our world launches an extraordinarily ambitious programme. It aims to achieve what the Millennium Development Goals (MDGs), which guided policy efforts of the preceding fifteen years, were not able to accomplish and to 'go far beyond' them. The 2030 Sustainable Development Agenda declares the aspiration that this generation will be the first to eradicate poverty in all its forms. The 2030 Agenda seeks fair and inclusive social, economic and cultural development for all and focusses urgency on extreme developmental difficulties. Achievement of the 17 goals and 169 targets requires the 
concerted mobilisation of diverse resources. In setting out a comprehensive set of goals that it contends are 'integrated and indivisible' it proposes to balance the three dimensions of sustainable development: the economic, social and environmental.' The document spells out the immense challenges facing the world; it stresses that billions of the worlds citizens 'continue to live in poverty and are denied a life of dignity.' Amid rising inequalities within and among countries are 'enormous disparities of opportunity, wealth and power. Gender inequality is exceedingly slow to change, with little progress achieved under the MDGs. The new Agenda aims to eliminate violence against women and girls and to implement a 'systematic mainstreaming of a gender perspective' to achieve the sustainable development goals (SDGs).

As sustainable development is dependent on the planet's natural resources, wide commitment to careful use of those resources is demanded. That in turn requires the concerted fostering of peaceful, just and inclusive societies. The new Agenda requires a 'global partnership' of solidarity that will promote understanding, tolerance, mutual respect and an ethic of global citizenship and shared responsibility among the world's peoples. The Agenda aims to eradicate poverty in all its forms and dimensions, including extreme poverty. That eradication by 2030 is the 'greatest global challenge' and it is indispensable for sustainable development. Education is an indispensable factor in that challenge. Goal 4 of the 17 SDGs declares: to 'ensure inclusive and equitable quality education and promote lifelong learning opportunities for all'. Everyone, everywhere, the Agenda declares, should have access to lifelong learning opportunities to enable them to develop and to participate in society.

Prospects for developing lifelong learning of that order require a substantive shift from lifelong learning and adult education of a predominantly instrumental and economic utilitarian character. For critics in developed countries long disappointed with the truncation of lifelong learning and defeated humanism there may seem little likelihood of that shift. Nonetheless, the 2030 Agenda, along with Rethinking Education, open fresh opportunity for 
visionary and diversely practical lifelong learning and adult education. Our discussion of a Ghana case study demonstrates those developments.

\section{Adult learning and education projects in Ghana: social development and empowerment}

Ghana has seen significant developments over the past decade. Its considerable progress on indicators of social and economic development (Lenhardt 2015; UNESCO 2014; World Bank 2011) are accompanied by establishing democratic political institutions and notable improvements in gender equity and women's social participation (Darvas and Balwanz 2014). The government has introduced developments in education over the last decade that aim to meet international benchmarks. Its Education Strategic Plan (2010 - 2020) (Ghana Ministry of Education 2010) is purposely influenced by the UN's Millennium Development Goals, now the Sustainable Development Goals, and by UNESCO's Education for All goals. It includes adult education and non-formal education.

Ghana's programmes to eliminate the worst forms of child labour (Ghana Statistical Service 2014; ILO-IPEC 2015) and to improve children's participation in formal schooling are generating improvements (UNESCO 2015b; Ghana Ministry of Education 2014; World Bank 2010). Alongside concerted efforts to improve schooling and vocational education, Ghana's Ministry of Education's Non-Formal Education Division (NFED) (http://nfed.gov.gh) endeavours to mainstream non-formal education in the national education system. It especially promotes inclusive adult education. NFED's flagship programme the National Functional Literacy Programme (NFLP) aims to improve adult literacy rates and provide basic education to acheive a range of life competencies. The literacy programme, in operation for three decades, is yielding positive results (Ghana Ministry of Education 2014).

These are very significant developments. Nonetheless, some serious problems persist. Fewer adults report no functional literacy, but the quality and durability of literacy is frequently poor (Darvas and Balwanz 2014; UNESCO 2015). Tagoe's study (2011) of the Ghana Poverty Reduction Strategy reports that government commitment to adult literacy appears erratic. Significant disparities in literacy rates between rural and urban areas, gender and socio- 
economic groups remain. Women's literacy rate is persistently lower then men's. The sustained participation (being in school most school days throughout the school year) of children aged $8-14$ is erratic and in some rural areas it is very poor. Child labour of $8-14$ year-olds at $27 \%$ remains high (Ghana Statistical Service, 2014). Child labour, it must be noted, does not mean children helping with family and household chores or performing paid work for a few hours a week. That degree of children working as part of household economies is both commonplace and broadly accepted as positive part of life. Child labour means children under 14 years old working in jobs instead of going to school. In rural areas, it is estimated that one third of child workers perform hazardous labour. Ninety-seven percent of child workers aged $5-7$ suffer notable injuries. Children are maimed and killed as a result of labour accidents (Ghana Statistical Service, 2014). Improvement in regard to these factors is slow or in some sectors it is stalled. Child labour is a complex issue of many intersecting factors. Adult parental education is a key factor in sustaining children's school participation and preventing child labour. Nearly a third of adults in Ghana have never been to school (Darvas and Balwanz 2014, page 48). Much effort to include adults in learning and education involves non-formal education provisions.

Educationists have long noted that measurement and evaluation of non-formal education is difficult (Singh 2015; Titmus 1989). The benefits of non-formal and personal adult learning and education can be opaque or of delayed fruition (Käpplinger and Robak 2014).The flexible structure of non-formal education, and its mix of formal and informal goals pursued by formal providers combined with the voluntary nature of adult participation can render quantitative survey data of limited use. Respondents to international survey data requests are often desk-bound officers doing their best to appraise educational activities frequently at considerable geographic distance from the centre. They can receive reports of numbers of participants and programmes provided but know little of the sustained participation of adult enrollees or the quality of their education and its effective outcomes.

In order to gain more in-depth perspectives and well-rounded appraisal of adult learning and education and functional literacy outcomes, we undertook a field study in Ghana 
in 2015. We visited and observed numerous sites of non-formal adult learning and education in the Greater Accra and Eastern Region of Ghana. We met with various adult learning and education actors: learners, teachers, coordinators, directors, policy advisors, Government and NGO actors. We observed different modes, sites and means of adult learning and education in delivery. We me with and listened to adult learners and tutors in villages and small cities talk about their experiences and outcomes. The field sites visited included village learning circles, small cooperative enterprises in plantations, government rural offices, a private (Church-run) university, a state university, Government Ministry offices and NGO offices. More than 90 persons directly contributed data.

We were especially interested in ascertaining effects of non-formal adult learning and education for communities. We focus on five principle and intersecting issues: improved gender equality through the education of women, improved economic development for village communities, improved participation in civic political affairs, action toward diminishing hazardous child labour, and environmental sustainability. Our study did not extend to appraising community health benefits resulting from adult learning and education in lowincome countries which other researchers have importantly identified and which entails a more extensive investigation (English 2012; Preece 2014). At the base of the benefits our study highlights is effective, sustained adult literacy. Through our in-person interviews and conversations with individuals and groups (in which language translation was simultaneously provided) we heard learners and educators report and reflect on the fruits of their learning.

A coordinator and facilitator of adult learning and education, reflecting on decades of experience in rural Eastern Region, reported that he had witnessed 'tremendous benefits' of adult education in the lives of adults and their village communities. He explained how participation in adult education, usually provided through an initial 21 month programme of functional literacy and follow-up group learning sessions, brought tangible and intangible benefits in enabling people to form and sustain a portfolio of new capabilities that led to visible transformation of their lives. Learners provided detailed illustrations of these new capabilities and how they are enriching their lives: 
Women learners reported what they considered to be dramatic changes to their lives: 'At first, when they started bringing [adult learning and education] to our village, we [women] would hide behind trees and try to listen. The men wouldn't let us come and sit with them. The tutors said we could come. So then the men let us come but we weren't allowed to talk... But now we do! Consequently, women had learned to speak out in village meetings and to take leadership roles, and men were learning to accept those changes. These steps toward gender equality and shared adult participation in the political and civic life of the community are also evident in economic life in the village.

Villagers spoke of gaining skills and competencies for starting and sustaining small cooperative income-generating enterprises in which traditional food stuffs (gari processing from cassava tubers) are processed for market trading. Members of these co-operatives reflected on how their gaining of literacy and basic education had also brought competencies that enabled their further development. They reported learning how to cooperate with members of different religio-cultural communities. Their shared experiences in adult literacy learning circles encouraged them to develop better relations with diverse others and to help each other maintain literacy competencies after their non-formal education programme ended. A co-op member said: 'We're about half and half Christian and Muslim in this co-op. We talk together; we get along. We respect each other's holy days, we help each other and our children.' Co-op group members spoke of how learning to make their co-op work successfully, which includes that tolerance and accommodation of different religious holidays and obligation, has brought them together and sustained member commitment. It has encouraged them to learn new things about markets and the production of their agricultural products, including understanding prices. Members of one of the co-ops we visited reported how they had collectively taken a decision to invest in an innovative new oven. The new oven, which they demonstrated to us, required less firewood, was higher yielding, and produced less smoke and irritation for the workers. (It was also less hazardous for infants nearby). The villagers had subsequently experimented with product innovation and expanded their market to a larger town centre. 
These points illustrate the integrated character of their community-based adult learning and education. Adult learning spills-over into cross-generational learning. Many of the adult learner respondents in this study reported that their first experiences of organised non-formal education was when they were in their mid-life years. One respondent reported that she was 41 years old before she began non-formal adult education classes in her village. She participated in her community's functional literacy programme. Of particular note in her story is the way she sustained her literacy, which is often fragile when first gained in adulthood. Literature and reading material are frequently scarce in rural communities that often rely on radio and word of mouth for news. Our respondent chose, at her own initiative, to regularly read her Bible at home. While reading the scriptures was in itself important to her, her selfdirected and disciplined study enabled her able to simultaneously maintain her literacy and contribute follow-on benefits to her family: 'Now my grandchildren see me reading at home because I want to... Now they [grandchildren] are staying in school. They are not going to the fields.' That illustration further points to the role of adult learning and education in addressing the social problem of child labour.

Child labour frequently occurs even when villages are free from food scarcity in part because many adults do not understand why it is a problem and why children fare better when they participate in formal schooling. Learners and educators spoke of the role of adult learning and education in enabling parents to understand why hazardous child labour is dangerous for children and harmful to their communities and broader societies and why its elimination urgent. Diminishment of child labour has been slow over the last decade.

A particular project conducted by the International Labour Organisation in partnership with the NFED and other government and NGO agencies sought to empower village leaders and communities to work together to stop the worst forms of child labour ${ }^{1}$ in cocoa production. The Cocoa Communities Project (ILO-IPEC 2015) sought to promote thriving cocoa growing

\footnotetext{
${ }^{1}$ In the case of rural Ghana communities, worst forms of child labour refers to $5-14$ yearolds working in the agricultural sector including in land clearing, using machetes and harvesting hooks, working in the vicinity of pesticide spraying, and carrying heavy loads in the production of cocoa and palm oil.
} 
communities in which all children are at school and out of child labour. A key strategy for achieving this objective was community-based adult education intervention².

Adult and parental education led to real changes in the circumstances of the communities resulting in better environments in which child labour is not encouraged. Villagers, farmers and coordinators report beneficial outcomes for communities. Some communities have now passed their own by-laws banning child labour. Villagers report that they have become aware of 'labour scouts' for multinational companies. Their newly learned competencies have empowered them to resist those scouts and to try to demand better labour relations for adult workers with officially registered and monitored employers. Labour organization actors report that the improving capabilities among rural communities also lead to greater awareness of the problems of trafficking of women and girls and efforts to reduce it.

In the course of learning in the cocoa communities project provisions, and other NFED literacy and basic education for rural development provisions, adult learners spoke of gaining new knowledge about broader community issues. They have learned about improved agricultural techniques which generate higher yield and also reduce the types of jobs often performed by children. In this way, they have learned to reduce non-hazardous as well as hazardous child labour. They report learning about environmental sustainability and the shared resources of water and soil. Learners reported: 'We've learned about pesticides. We need to be careful and not over-use them. They can be harmful to us. Pesticides affect our water and we're learning to be more careful about water.'

The provision of integrated, community based adult education has enabled these illustrations of accomplishments and their evident potential for subsequent community and societal developments. Adults who participate in functional literacy and numeracy programmes demonstrate and report experiencing stimulation of interest in gaining diverse knowledge development subsequent to that basic learning. They demonstrate increased cognitive skills,

\footnotetext{
${ }^{2}$ Details of ILO-IPEC Cocoa Communities Project (CCP) can be found at http://www.ilo.org/ipec/Informationresources/WCMS IPEC PUB 27315/lang--en/index.htm. The Ghana intervention was implemented over a 44-month period ending in April 2014 in 40 communities across seven districts in the Western, Central and Eastern Regions of Ghana. Its effort to eliminate child labour also sought to promote community-led holistic development initiatives in education, health, infrastructure, livelihood and improved technical capacity.
} 
curiosity and ambition for improved community socio-economic and political development. Adults gain understanding of notions of political rights and community protection. They gain an imagination of capability that they may participate in shaping their lives rather than being subject to fate and determination by powerful elites.

The case study demonstrates benefits of holistic adult learning and education, which is at core humanistic in its endeavor to provide plural resources and developments for human flourishing in this particular context. Our intention to report concrete benefits also draws attention to questions in regard to factors that make successful adult learners whose continuing learning generates and reaps future benefits for their communities. In this short paper, we remark on two key factors. A core vital factor is that of sustained provision of adult learning and education. In the first instance, adult literacy can be fragile. Its retention for people who have gained literacy later in life needs careful attention. Follow-up active and regular reading at home is essential to avoid lapsing into illiteracy. This study shows that self-chosen continuing reading at home, such as adults reporting self-directed reading of sacred scriptures, in their local language at home simultaneously sustains and disperses broader competencies and skill development. It encourages capacities of reflection and confidence, it maintains personal literacy, and it models at-home, pleasurable reading to children. It enables, furthermore, vital competencies for adults to read instructions on pesticide containers, notifications from authorities or multinational companies and develop advanced political participation in society.

A second, less visible and eminently humanistic factor arises in the quality of tutors. In the course of our field study, we witnessed and heard about the role of high quality adult learning and education tutors. Salient among the most successful programmes was the exceptional high quality of some educators and leaders. Tutor excellence comprises a highly significant factor in the success of adult learning and education provision and its benefits to communities over time. One of the rural adult learning groups, of twelve years formation, reported to us about the particular role of their senior-aged tutor. The tutor (to whom we were introduced), it was widely confirmed, 'loved' his adult learners and 'stayed 
with them' through difficult times. The sustained adult learning circle and cooperative group accord much of their development to the role of that teacher. This illustration of an intrinsic and affective humanism underpinning successful adult education provision is further supported by other studies within African contexts. Baba-Moussa and colleagues (2014), for instance, demonstrate the fundamental importance of morally and culturally embedded adult education in African philosophies and undertakings in ALE.

\section{Discussion: Adult education, transformation, sustainability}

International debates, including those led by global agencies, academic and NGO researchers, and government actors, increasingly embrace the complexities of the world's diverse cultures and world views. As Rethinking Education acknowledges, our increased recognition and respect for human cultural diversity is both a vast resource and immense challenge. The complexity of cultural diversity in world views and lived realities can make it very difficult for vision-setters and policy actors to find agreement on what features and goals ought to be pursued and how they should be prioritised. While endeavouring to listen to each other and learn from different world views, there is a risk of Western-styled viewpoints and ways of doing things being practically reasserted over others in order to avoid protracted delays or inefficiencies while interlocutors are discussing principles among themselves. Rethinking Education demands that while recognising our diversities, we must reaffirm 'a common core of universal values' (UNESCO 2015 page 29). Finding that common core of values may require not only recognition of what we have learned from profound reflection on the past but on listening to 'voices from the global South.' Those voices and those from rural societies must richly inform international debates that are so often dominated by Westerncentric perspectives.

The Ghana case study informs international debates on several counts. Firstly, it brings to attention voices from the global South and rural communities in regard to education and particularly adult learning and education. Those voices, in this case, are not intent on expressing complaint against their marginalisation by powerful others, demanding redress or 
protesting the inadequacies of conventional international policies imposed upon them (although there obviously remain grounds for doing so that are beyond the purview of our discussion in this article). The Ghanaian voices in this study are intent on expressing their reflective evidence on what they value, what they are doing and what they are achieving through their actions. They have learned that their non-formal adult education provision and their ways of conducting it are making a transformative difference to learners and their communities. It is that knowledge, with its irreducible humanism and its potential to inform broader international debate, that participants in this study sought to contribute.

Secondly, the study brings into view the ways that efforts to provide adult learning and education in that country's specific context embody the overt values of improvement of the quality of villagers' lives. That quality of life includes not only better material conditions but the dignities of human cultural development, as in the fruits of sustained adult literacy, empowerment to participate in civic life and decision-making, greater gender fairness, and freedom from child labour in their communities. A key part of that 'quality of life' was the quality of relationships among groups and communities and their abilities to accommodate diversity while working for their common good.

On this point, Rethinking Education's aspiration to identify and reaffirm 'a common core of universal values', is richly assisted. Quality of life and not just of economic development, as though instrumentally abstracted from socio-cultural value, is pursued as fundamental value. A further common value may be claimed as that of sustainability in regard to planetary resource. The Ghana case illustrates both growing awareness of that value as one in common within and across communities and society and of efforts to protect that value. Respondents reported their awareness of caretaking of natural resources such as water, soils and forests that sustain their communities.

Rethinking Education additionally proposes that a common value for education is its role in empowerment and development of capabilities that effect social transformation. On that count the Ghana case illustrates valuation and pursuit of that goal. In endeavouring to accomplish greater gender fairness and inclusive participation, and to eliminate child labour 
in their communities - both tenaciously challenging problems - villagers demonstrate that value and effect of adult learning and education.

A third feature of the Ghana case is its demonstration that the goals elaborated in Transforming Our World, while greatly ambitious in scope and timetable, have credibility. There is without doubt great challenge ahead in distributing the benefits of adult learning and education reported in this study across all regions and communities within Ghana. But the illustrations of a robust, pro-social humanism guiding the formulation and implementation of non-formal adult education programmes provide sound reason for optimism and sustained commitment to the task. The transformation underway for villagers through the carrying out of adult education by partner bodies of government officers, NGOs and community actors in rural communities proposes to make real progress toward achieving the sustainable development goals of the 2030 Agenda.

\section{Conclusion}

UNESCO has long promoted a view of democratic and peaceful societies that require for their sustenance our continuing reflexivity and renewed efforts to cooperate. Lifelong learning as a philosophy directly supports that endeavor. Despite the various ways in which lifelong learning and activity have been conceived and practised, there remains a core element of inclusivity and universality. Lifelong learning is a shared call for all of us in our particular contexts.

The Ghana experience demonstrates the vitality of non-formal adult education and its essential part of lifelong learning. It shows the transformative power of adult learning and education to bring improved quality of life, greater justice and sustainability to communities. For that experience to be more widely replicated - in developed as well as developing economies - greater cooperation between policy-makers, research academics and adult education practitioners is needed. While critics rightly must scrutinise and interrogate educational activities, their contributions to practice may add further value when policy critique is less hostile and distancing, as that exemplified in Griffin's (2006) critique of policy- 
makers as the 'other' of lifelong learning educators. Fresh thinking encourages new learning across fields and vantage points that generates a more generous, mutually informed approach. The transformative power of adult education, evident in the empowerment of villagers to create income-generating, culturally diverse and inclusive cooperatives with political capabilities to shape their communities, is a vital instrument in the UN's goals for transformation and human flourishing. Equally, the coordinated and integrated education of adult farmers, parents and child labourers demonstrates the power of conjoined humanistic and practical ethics in application to labour practices to change rural Ghanaians' lives and envision a more just, peaceful and sustainable future.

\section{Acknowledgements}

The authors gratefully acknowledge the assistance of the Ghana Ministry of Education and UNESCO Ghana office in facilitating the field study and access to rural adult education activities and sites. We especially thank the many adult learners and tutors who generously shared their knowledge and reflections with us.

\section{References}

Aman, R. and Ireland, T. 2015. Education and other modes of thinking in Latin America, International Journal of Lifelong Education, 34(1): 1-8.

Baba-Moussa, A., Moussa, L. and Rakotozafy, J. 2014. Fondements et philosophie de l'education des adultes en Afrique, Hamburg: UIL.

Casey, C. 2011. Economy, Work and Education: Critical Connections, New York and London: Routledge. 
Darvas, P. and Balwanz, D. 2014. Basic Education beyond the Millennium Development Goals in Ghana, Washington, D.C: World Bank.

Denys, K. (ed.) 2013. Adult Education and Social Change: Jordan, Palestine, Lebanon, Syria, Egypt. Bonn: Deutschen Volkshoschul-Verbandes International.

Elfert, M. 2015. UNESCO, the Faure Report, the Delors Report, and the political utopia of lifelong learning. European Journal of Education. 50 (1): 88-100.

English, L. (ed.) 2012, Adult Education and Health, Toronto: University of Toronto Press.

Field, J. 2006. Lifelong Learning and the New Educational Order. Stoke on Trent: Trentham Books.

Fragoso, A., Kurantowicz, E., Lucio-Villegas, E. (eds.) 2011. Between Global and Local Adult Learning and Development. Berlin: Peter Lang.

Freire, P. 1968. Pedagogy of the Oppressed. New York: Continuum.

Ghana Ministry of Education. 2010. Education Strategic Plan 2010-2020. Accra: Ministry of Education.

Ghana Statistical Service, 2014. Child Labour Report 2014, Accra: Government of Ghana GSS.

Green, A. 2011. Lifelong Learning, Equality and Social Cohesion. European Journal of Education, 46 (2): 228-243. 
Green, A., Preston, J. \& Janmaat, J.-G. 2006. Education, Equality and Social Cohesion: A Comparative Analysis. Basingstoke: Palgrave.

Griffin, C. 2006. Research and Policy in Lifelong Learning, International Journal of Lifelong Education, 25 (6): 561-574.

Heikkinen, A. 2012. Practicing learning instead of mobilizing a movement: neo-liberation of adult education? Lifelong Learning in Europe Vol. XVII Issue 1 pp 65 - 69.

ILO-IPEC 2015. International Labour Office (ILO) International Programme on the Elimination of Child Labour (IPEC). Good practices and lessons learned in cocoa communities in Ghana. Geneva: International Labour Office.

Janmaat, J. and Green, A. 2013. Skills Inequality, Adult Learning and Social Cohesion In The United Kingdom, British Journal of Educational Studies 61(1):7-24.

Jarvis, P. 2010. Inquiry into the Future of Lifelong Learning, International Journal of Lifelong Education, 29 (4): 397-400.

Jenkins, A. 2011. Participation in learning and well-being among older adults. International Journal of Lifelong Education 30 (3): 403-420.

Käpplinger, B. and Robak, S. (eds.) 2014. Changing Configurations in Adult Education in Transitional Times, Berlin and Brussels: Peter Lang.

Lenhardt A., Rocha Menocal, A. and Engel, J. 2015. Ghana, the rising star: Progress in political voice, health and education, London: Overseas Development Institute 2015.

Livingstone, D. and David Guile, D. (eds.) 2012. The Knowledge Economy and Lifelong Learning: A Critical Reader, Rotterdam: Springer. 
Manninen, J. 2010. Wider Benefits of Learning within Liberal Adult Education System in

Finland. In: Horsdal, M. (ed.) Communication, Collaboration and Creativity: Researching Adult learning. Odense: Syddansk Universitetsforlag.

OECD 2014a. Learning Begets Learning: Adult Participation in Lifelong Education. Paris: OECD Publishing.

OECD 2014b. Education at a Glance 2014. Paris: OECD Publishing.

OECD 2009. Education at a Glance 2009. Paris: OECD Publishing.

Preece J. 2014. Lifelong learning in Africa: a contribution to development. Andragogigal Studies 2, 69-76.

Regmi, K. 2015. Can lifelong learning be the post-2015 agenda for the Least Developed Countries?, International Journal of Lifelong Education DOI:10.1080/02601370.2015.1070209

Rodrigues, M. 2003. European Policies for a Knowledge Economy, Cheltenham UK: Edward Elgar.

Rubenson, K. 2011. The field of adult education: and overview, in Rubenson, K. (ed.) Adult Education and Learning. Oxford: Elsevier.

Scheutze, H. and Casey, C. 2006. Models and Meanings of Lifelong Learning. Compare: The British Journal of Comparative Education 36 (3): 279 - 287.

Schuller, T., Preston, J., Hammond, C., Brasset-Grundy, A. and Bynner, J. (2004) The Benefits of Learning: the impact of education on health, family life and social capital, London: Routledge Farmer. 
Singh, M. 2015. Global Perspectives on Recognising Non-formal and Informal Learning: Why recognition matters. Hamburg: UNESCO Institute for Lifelong Learning and Springer Open.

Tagoe, M. 2011. Accelerating the achievement of the Millennium Development Goals in Ghana: literacy, the missing link, International Journal of Lifelong Education, 30(5): 651-666.

Titmus, C. (ed.) 1989. Lifelong Education for Adults, Oxford: Pergamon.

UNESCO 2015a. Rethinking Education: Towards a global common good? Paris: UNESCO.

UNESCO 2015b. Education for All Global Monitoring Report 2000 - 2015: Achievements and challenges. Paris: UNESCO.

UNESCO 2010a. Belem Framework for Action. Hamburg: Institute for Lifelong Learning.

UNESCO 2010b. Global Report on Adult Learning and Education. Hamburg: UNESCO Institute for Lifelong Learning.

Walters, S. Yang, J. and Roslander, P. 2014. Key Issues and Policy Considerations in Promoting Lifelong Learning in Selected African Countries: Ethiopia, Kenya, Namibia, Rwanda and Tanzania, UIL Publication Series on Lifelong Learning Policies and Strategies: No. 1 Hamburg: UNESCO Institute for Lifelong Learning.

Walters, S. and Watters, K. 2001. Twenty years of adult education in Southern Africa, International Journal of Lifelong Education, 20 (1-2): 100-113.

Webb, S.; Holford, J.; Jarvis, P.; Milana, M. \& Waller, R. 2015. Global policy agencies and visions for twenty-first century lifelong education, International Journal of Lifelong Education, DOI: $10.1080 / 02601370.2015 .1075335$ 
Welton, M. 1993. Social Revolutionary Learning. Adult Education Quarterly 43, no.3: 152164.

World Bank 2011. Tackling Poverty in Northern Ghana. Washington, DC: World Bank.

World Bank 2010. Education in Ghana: Improving Equity, Efficiency and Accountability of Education Service Delivery. Washington, DC: World Bank.

World Bank, 2003. Lifelong Learning in the Global Knowledge Economy: challenges for developing countries, Washington D.C.: The World Bank.

Zarifis, G. and Gravani, M. (eds.) 2014. Challenging the 'European Area of Lifelong Learning': A Critical Response. Dordrecht: Springer.

Zeelen J., Rampedi M., De Jong G. 2011. Adult education in South Africa: Challenges for implementation. International Journal for Lifelong Education, 30 (3): 385-402. 